
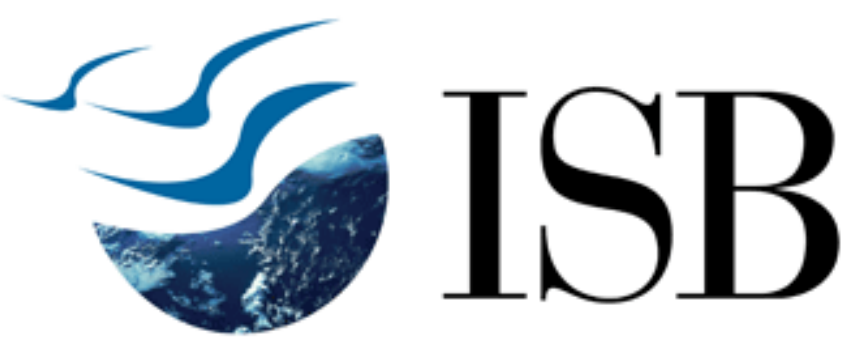

Does Regulator Selection of Auditors Improve Audit Quality? Evidence from Auditor Designation in Korea

http://eprints.exchange.isb.edu/87

Working Paper

Indian School of Business

2013 


\title{
Does Regulator Selection of Auditors Improve Audit Quality? Evidence from Auditor Designation in Korea
}

\author{
Gil Bae \\ School of Busines \\ Korea University \\ Seoul, Korea 136-701 \\ Phone: +82-2-3290-1951 \\ gilbae@korea.ac.kr \\ Sanjay Kallapur \\ Indian School of Business \\ Gachibowli, Hyderabad 500032 \\ Phone: +91 4023187138 \\ Sanjay_kallapur@isb.edu \\ Joon Hwa Rho \\ College of Business \\ Chungnam National University \\ Daejon, Korea \\ Phone: +82-42-821-5544 \\ jhrho@cnu.ac.kr
}

First Draft: September 2010

Current draft: March 2012

We thank Krishnamurthy Subramanian and seminar participants at the University of Arizona, and the European Accounting Association for helpful comments. 


\title{
Does Regulator Selection of Auditors Improve Audit Quality? Evidence from Auditor Designation in Korea
}

\begin{abstract}
Although the hiring and firing of auditors by clients is believed to create a fundamental conflict of interest, there is little research on the issue except for experimental evidence in Mayhew and Pike (2004). To provide evidence on the issue, in this paper we exploit the setting in Korea, known as auditor designation, wherein regulators selectively and episodically selected auditors for certain client firms. We fail to find that audit quality proxied by absolute discretionary accruals, audit hours, modified opinions, and the tendency to meet or beat benchmarks, is higher for designated auditors. Our results therefore question whether hiring and firing of auditors by clients is a threat to auditor independence.
\end{abstract}

Keywords: auditor designation, regulator selection of auditors, audit quality, auditor independence.

JEL Classification: G38, M48, 


\section{Does Regulator Selection of Auditors Improve Audit Quality? Evidence from Auditor Designation in Korea}

\section{Introduction}

The practice of client managers hiring and firing auditors is believed to cause a fundamental conflict of interest that could impair auditor independence (Burton, 1980; Saul, 1996; Bazerman et al., 1997; Kinney Jr, 2000; Abdel-khalik, 2002; Bazerman et al., 2002; O’Connor, 2004; Shapiro, 2005; O’Connor, 2006; Ronen, 2010). Warren Buffett expresses this idea quoting a German proverb "Whose bread I eat, his song I sing" (Hilzenrath, 2001). In the wake of Enron, several authors (Abdel-khalik, 2002; Palepu \& Healy, 2003; O'Connor, 2004; Shapiro, 2005; O’Connor, 2006; Ronen, 2010) have advocated removing managers' control over hiring and firing of auditors, and giving it to regulators, stock exchanges, or independent shareholder trusts monitored by the stock exchange. In a related context there is regulatory action along these lines-for credit rating agencies, Section 939F (d) of the Dodd-Frank Act of 2010 requires the SEC to establish a system which removes the issuer's control over the selection of the credit rating agency.

While Burton (1980) and Kinney (2000) are sanguine about the possibility of auditor independence, they too argue that client hiring of auditors has a much greater potential for independence impairment than does the provision of non-audit services (NAS). Yet, while there is a lot of research on whether NAS impair independence, there is scant research on whether manager hiring of auditors impairs auditor independence. Mayhew and Pike (2004) is an exception; they provide experimental evidence, citing (p. 797) the 
lack of field settings with diversity in whether it is the company or an outsider that hires and fires the auditor.

Our research exploits a field setting outside the USA--in Korea--where under certain conditions the auditors for some client firms are designated, i.e., chosen, by the regulatory authority (Financial Supervisory Service, FSS) instead of by client firms. After designating a client firm's auditor, the FSS reconsiders every year whether to continue the designation or release the client from designation. If released, the client is free to choose their auditor, i.e., continue with the designated auditor, go back to the predesignation auditor, or get a new auditor. Designation is thus selective, i.e., in the population of client firms only a few are chosen for designation, and episodic, i.e., a particular designation episode lasts for a few years and then ends.

Auditor independence is expected to be stronger in this setting because as long as the designation lasts, auditor hiring and continuation decisions are made by the FSS rather than the client. Thus any auditor choices made for the purpose of opinion-shopping are disrupted, any negative effects of competition (Francis et al., 2010; Kallapur et al., 2011; Newton et al., 2011) and tendering (Fiolleau et al., 2009) are avoided, and the lack of competition prevents lowballing which is thought to impair auditor independence (Bandyopadhyay \& Kao, 2001; Hackenbrack et al., 2000; Maher et al., 1992). If the existing safeguards of auditor independence, such as a concern for reputation, are weak in comparison to these threats, we should observe higher audit quality for designated auditors.

Apart from being a real-world setting, this setting has two advantages from a research design point of view. First, as described in more details in Section 2, the FSS designates 
firms that are considered problematic, thus likely to have a greater incentive to unduly influence auditors; we are therefore more likely to find an effect if it exists. Second, because designation is selective and episodic, we can use contemporaneous nondesignated client firms, as well as the pre- and post-designation periods for the designated firm, as controls.

Like most natural experiments, however, this one is not perfect. First, designated firms are not selected randomly; this however is more likely to be an advantage rather than a disadvantage because, as argued above, the selection likely operates in such a way as to lead us to find that designation improves audit quality, contrary to what we find. Second, although there is no theoretical limit to the length of the designation period, in practice it lasts only 1-2 years. Therefore audit firms might still have some incentives to please the client, expecting to be re-hired by them in the future. Such incentives would be absent if, as proposed by some, auditors were hired by the regulator or the stock exchange permanently in the future; this limits the generalizability of our findings to provide evidence on the proposed reforms. To address this issue we examine the subsample where designation ex-post lasts more than three years. If auditors anticipate designation to last long, they would not have incentives to please the client because the designated auditor is compulsorily rotated after three years. Also, our findings do shed light on any independence impairment caused by opinion-shopping, competition or the tendering process, or by lowballing.

Using absolute discretionary accruals, audit hours, propensity to meet/beat or miss benchmarks, and modified opinions as proxies for audit quality, we fail to find consistent evidence that audit quality is higher under designation. Designated firms have higher 
absolute discretionary accruals and lower audit hours, both pointing towards lower audit quality. Evidence using signed discretionary accruals and modified opinions is statistically insignificant. The evidence using propensity to meet or miss benchmarks is mixed-designated firms are more likely to miss the zero earnings benchmark indicating higher audit quality, but there is no statistically significant evidence that they are less likely to meet that benchmark. Designated firms are less likely to meet, but also less likely to just miss the prior year earnings benchmark, which is contradictory evidence. The results are similar for the sub-sample of designation episodes lasting more than three years. Thus the results fail to support the proposition that audit quality would improve if auditor choice were removed from the client's hands.

Kim and Yi (2009) study the same setting, and contrary to our results, find that discretionary accruals are lower for designated firm-years compared to a control group consisting of firms whose auditors have never been designated. We are able replicate their results using their research design, but find that the results change when we include the non-designated periods of the same firms in the control group (with or without neverdesignated firms in the control group). Thus Kim and Yi's results are likely to reflect inherent differences between firms subject to designation versus those not subject to designation, rather than to the effect of designation. In addition, we also use additional measures of audit quality, namely audit hours, propensity to meet/beat or miss benchmarks, and modified opinions.

Our research contributes to the auditor independence literature by examining a fundamental feature of audit markets, namely client hiring and firing of auditors, that has the potential to impair auditor independence. While non-audit services have been 
extensively studied, this fundamental feature that has the potential to induce even more severe independence impairment, has been less studied, due to the paucity of settings where auditor hiring and firing is done by parties other than the client firm. There are only two previous studies, Mayhew and Pike (2004) and Kim and Yi (2009), on this issue, and they reach the conclusion opposite to ours. As mentioned above, our research design is superior to that of Kim and Yi. Our result is not directly comparable to Mayhew and Pike (2004) because theirs is an experimental setting. While experimental settings have the advantage that the experimental variable can be better manipulated and audit quality can be better measured, as Mayhew and Pike (2004, p. 817) acknowledge, they are necessarily abstractions and simplification of real-life settings. It is possible that our results differ from Mayhew and Pike because of the contextual features of real-world audit settings, such as professional standards and group affiliation (King, 2002), which are important in understanding the effects of client hiring and firing.

\section{Institutional Setting and Audit Quality Proxies}

\subsection{Institutional Setting}

Until 1984 the Korean Institute of Certified Public Accountants assigned auditors to clients, who therefore had no choice in the matter. This system was perceived to result in low audit quality because auditors had no incentives to improve, and therefore the "free engagement system" was introduced in 1984 (Koo \& Sim, 1999, p. 209). The audit quality under the free engagement system continued to be perceived as being low, as a result of "unfettered competition among auditors" (Lee, 1990). In an effort to improve auditor independence, the FSS introduced selective auditor designation in 1991. Specifically, the FSS designates the auditor for certain firms which need a more 
"impartial and fair audit" than "normal" firms (Act on External Audit of Stock

Companies, Article 4-3: Designation, etc., of Auditor by Securities and Futures

Commission ${ }^{1}$ ). If a firm is identified for designation then it must replace its existing

auditor with the designated auditor. In the following year, the designation requirement

may be continued or lifted. If continued, the client firm must continue with the same

auditor. If lifted, the client is free to continue with the designated auditor, or hire any

other auditor including its auditor prior to designation. If designation continues for the

fourth consecutive year, then the FSS appoints a new auditor. In short, the regulation

allows the FSS to appoint auditors for selected firms during the designation period

chosen by the FSS.

The FSS specifies the following reasons for auditor designation, which purported to identify the firms whose managers had the highest incentives to unduly influence auditors (Act on External Audit of Stock Companies, Article 4-3): (1) firms that did not select auditors within a specified period; (2) firms that changed auditors for unacceptable reasons; (3) firms that had negative audit reviews in the previous year; ${ }^{2}$ (4) firms that are manager-owned; (5) firms that have excessive loans (i.e., 30 percent or more relative to equity) or debt-guarantee (i.e., 10 percent or more relative to equity) to related parties; (6) firms that belong to the industries under restructuring; (7) firms that have a high (i.e., 150 percent or higher relative to the industry average) debt-to-equity ratio; (8) firms that are

\footnotetext{
${ }^{1}$ The Act on External Audit of Stock Companies was enacted on December 31, 1980 (Act No. 3297) and has been amended several times. The most recent amendment was on November 18, 2010 (Act No. 10303).

2 The FSS reviews the financial statements of roughly 20 percent of the listed firms each year. The review can be initiated either from random sampling or from the suspicion that the financial statements are misstated. If significant mis-statements are identified, then the firm and possibly the engagement auditor too would be sanctioned. For example, 13.1 percent of firms were reviewed in Year 2010--see FSS annual report of 2010 available at http://english.fss.or.kr/fss/en/publications/annual/view.jsp?bbsid=1289364303986\&category=null\&idx=13 $21575191868 \&$ num $=12 \&$ color=lgreen $)$.
} 
under the security trading restriction; ${ }^{3}$ (9) firms that violated the Securities Trading Laws;

(10) firms that are going public; (11) firms that are recommended by the credit-control

law; and (12) firms that are recommended by the fair trading practice law. ${ }^{4}$ The FSS

expects that "the auditor designation regulation will help assure auditor independence and increase public confidence in audit and thus protect investors" (the FSS press releases,

February 5, 2008 and January 29, 2009, available in Korean at

http://www.fss.or.kr/fss/kr/promo/bodobbs_view.jsp?seqno $=12825$ and

http://www.fss.or.kr/fss/kr/promo/bodobbs_view.jsp?seqno=13344 respectively).

To match an auditor to a client firm subject to designation, the FSS first rank orders audit firms by scores that are determined primarily by audit firm size. The FSS then ranks the firms by asset size. Finally, the FSS assigns the first auditor (i.e., the auditor with the highest scores) to the first firm (i.e., the largest firm) and the second auditor to the second firm, and this process continues until all the audit firms that are qualified to serve as designated auditors are assigned to firms. If there are still any client firms left in the list, the process is repeated until all client firms are assigned an auditor. This matching process makes it virtually impossible for a firm to predict who will be its designated

\footnotetext{
${ }^{3}$ The Security Exchange Law (Act No. 2920 enacted on December 22, 1976, now superseded), specified reasons for which trading of a firm's stock would be either prohibited or restricted.

${ }^{4}$ There are three other reasons for which auditors can be designated. However, no firms have been designated for those reasons, and therefore we exclude from further discussion. Firms that are going public are also required to hire a designated auditor, but we excluded them from the sample because they were private when the auditor was designated.

${ }^{5}$ Through amendments of the law in 2001 and 2006, the FSS subsequently dropped several of the reasons for designation. Specifically, the FSS dropped (4) firms that are manager-owned, (5) firms that have excessive loans or debt-guarantee to related parties and (7) firms that have a high debt-to-equity ratio because "the capital structure has been improved in most companies and firms choose the capital structure that best suits themselves" and "the securities trading law prohibited loans and debt-guarantee to related parties including the management and controlling owners in December 31, 2003," which make the reasons (5) and (7) unnecessary, respectively (The Ministry of Economy and Finance publication in December 12, 2005). The FSS provided no explicit explanation for deleting reason (4).
} 
auditor. Auditor designation thus ensures that auditors are not obligated to client managers for having appointed them. ${ }^{6}$

There are several (non-mutually-exclusive) reasons why client selection of auditors could affect auditor independence. First, if the auditor selection had been the result of opinionshopping, the forced discontinuation of the relation should increase audit quality. Second, several studies find a negative relation between competition and audit quality (Francis et al., 2010; Kallapur et al., 2011; Newton et al., 2011). Indeed, Fiolleau et al (2009) argue that the tendering process itself engenders behaviors that impair auditor independence-auditors win the business by demonstrating that they share the client's views and are flexible. Third, competition among auditors induces lowballing which is thought to impair independence (Bandyopadhyay \& Kao, 2001; Hackenbrack et al., 2000; Maher et al., 1992) and we show empirically that there is no evidence of lowballing by the designated auditor. On the other hand there are factors such as auditors' concern for reputation that safeguard auditor independence, and it is an empirical question which is stronger--the threats to auditor independence, or the safeguards. Evidence on the Korean setting is well suited for providing evidence on the above threats because the safeguards remained unchanged while auditor designation removes the above threats. Indeed our setting is almost ideal ${ }^{7}$ because designation is selective and episodic, thereby enabling us to use non-designated firms as well as pre- and post-designation periods of the designated firms as controls. One could instead study changes in audit quality of Korean firms after

\footnotetext{
${ }^{6}$ SOX now requires the audit committee to select auditors, and Korea has similar requirements (Act on External Audit of Stock Companies, Article 4: Selection and Appointment of Auditor), but they might not truly represent shareholders (Bazerman et al., 2006 p. 44). In a field study, Fiolleau et al. (2009) confirm that managers continue to have a strong influence on auditor selection.

${ }^{7}$ It does not match the full ideal of random assignment of firms to the designated category. However, we attempt to control for selection effects, and because the most problematic firms are selected for designation the bias is likely towards finding an effect, the opposite of our results.
} 
1984 when the free engagement system was introduced, but the problem is that all firms changed simultaneously, so there is no contemporaneous control group, and there could be many confounding factors affecting changes in audit quality over time.

Unfortunately, however, the natural experiment is not perfect. FSS is allowed to release a firm from designation at any time, and in practice each episode of designation lasts only1-2 years. Therefore the expectation of future audit fees after release from designation could still economically bond auditors to clients. Compared to voluntarily chosen auditors, designated auditors are more likely to be replaced post-designation. So designated auditors likely have greater incentives to be independent, but it is theoretically ambiguous. ${ }^{8}$ To that extent our findings may not generalize to settings where auditor choice is given to outside parties once and for all. We address this issue by examining the sub-sample of designated client firms where designation ex-post lasted more than three years. As mentioned earlier, designated auditors are compulsorily rotated after three years. So, to the extent that auditors foresee a long designation period, they know they are sure to be replaced and therefore do not have incentives to compromise their independence.

\footnotetext{
${ }^{8}$ During our 1993-2008 sample period, voluntarily-chosen auditors have been switched 15 percent of the time (i.e., in 2,135 out of 13,415 firm-years). When firms are released from auditor designation, however, the switch rate is much higher, 47 percent ( 257 out of 547 firm-years immediately following release from designation). Auditors' incentives to remain independent depend on the differential amounts of (a) costs of compromising their independence, e.g., detection and sanctions or reputation loss, in the two settings, and (b) benefits, i.e., expected increase in probability of continuation for a given amount of compromise. If costs are the same, and a given amount of compromise reduces the probability of being fired from 100 percent to 15 percent for voluntarily-chosen auditors and 100 percent to 47 percent for the designated auditors, then designated auditors are less likely to compromise their independence. However, researchers cannot observe the auditor's probability of being fired absent compromise, and it could differ for voluntarily-chosen and designated auditors, so it is not possible to assert unambiguously that designated auditors have fewer incentives to compromise.
} 


\subsection{Proxy for Audit Quality}

\subsubsection{Discretionary Accruals}

Because audit quality is not directly observable or quantifiable, prior studies have used various proxies. One commonly used proxy for audit quality is earnings quality, which is, in turn, has relied on discretionary accruals as a proxy. ${ }^{9}$ Following the literature, we use discretionary accruals as a proxy for audit quality. Francis and Krishnan (1999) argue that accruals reflect managers' accounting discretion and subjective estimates and highquality auditors constrain managers from making biased estimates for earnings management purposes.

While discretionary accruals are a commonly used proxy for audit quality, the specific measures used in prior studies vary. Some use absolute accruals, e.g., Johnson et al. (2002), Chung and Kallapur (2003), and Myers et al. (2003); while others use signed accruals or both, e.g., DeFond and Subramanyam (1998), Frankel et al. (2002), Hamilton et al. (2005), and Carey and Simnett (2006). Since extreme accruals in both directions (i.e., income increasing and decreasing) may indicate potential earnings management, auditors may be concerned about both the absolute and signed values of accruals.

Following the above literature we use both types of accruals, namely signed discretionary accruals and absolute discretionary accruals, as a measure of audit quality.

\subsubsection{Other proxies}

In addition, we also use audit hours (Deis \& Giroux, 1996; Palmrose, 1989), the tendency to meet or beat benchmarks (Ashbaugh et al., 2003; Frankel et al., 2002; Lim \& Tan,

\footnotetext{
${ }^{9}$ See, for example, Becker et al. (1998), DeFond and Subramayam (1998), Francis and Krishnan (1999), Bartov et al. (2000), Bradshaw et al. (2001), Frankel et al. (2002), Johnson et al. (2002), Ashbaugh et al. (2003), Chung and Kallapur (2003), Myers et al. (2003), Ghosh and Moon (2005), Hamilton et al. (2005), and Carey and Simnett (2006).
} 
2008), and modified opinions (Bradshaw et al., 2001; DeFond et al., 2002; Lim \& Tan, 2008) as additional proxies for audit quality.

\section{Sample Selection and Descriptive Statistics}

\subsection{Sample}

Our sample consists of all non-financial firms listed on the Korean Stock Exchange (KSE) during the 1993-2008 period. The KSE consists of two exchanges, the Korea Composite Stock Price Index (KOSPI) and Korean Securities Dealers Automated Quotations (Kosdaq). Generally, Kosdaq firms are smaller and therefore not comparable to KOSPI firms. Hence, we use only KOSPI firms in our analysis, although results are qualitatively unchanged if Kosdaq firms are also included in the analysis. The auditor designation regulation came into effect in 1991, but we begin our sample period in 1993 because it is the first year for which we have audit fee data. We collected the information about auditor designation from the database complied by the FSS (dart.fss.or.kr). ${ }^{10}$ We obtain the financial statements data used to calculate discretionary accruals and as control variables from a database supplied by the Korea Investors Service, Inc. Value (KISValue). Finally, we obtain information about audit fees from the Korean Institute of Certified Public Accountants. We choose firms with December year-end to ensure that financial data is correctly matched with audit fee data. Since almost all the firms in KOSPI have December year end, this requirement is not overly restrictive. ${ }^{11}$ In all, there are 1,024 (11.9 percent of total firm-years) auditor designated firm-year observations in our final sample out of 8,618 total firm-year observations.

\footnotetext{
${ }^{10}$ From 2004 onwards the FSS provides only the list of the auditor designated firms without specifying the reason(s) for designation, which partly contributes to our inability to fully calibrate the reasons for designation in our sample (shown as "unidentified reasons" in Panel A of Table 1).

${ }^{11}$ All financial firms are required to have March year-end in Korea, which accounts for the majority of non-December-year-end firms.
} 
Figure 1 depicts the yearly number of client firms whose auditors were designated during our sample period. The number of auditor designations peaks in the year 1998, with 137 client firms. Since then, the number has been declining for two reasons. First, after the Asian financial crisis of 1997 , firms were required to lower their debt-to-equity ratio below 200 percent by a government regulation. Also, in the aftermath of the crisis, in 2003 the securities trading law prohibited loans and debt guarantees to related parties including the management and controlling owners. Therefore, most firms no longer are subject to auditor designation for the reason of either high debt-to-equity ratio or loans and debt guarantees to related parties. Second, perhaps partly because of the first reason, the FSS eliminated several reasons, including the above two, for audit designation in 2001 and 2006. Specifically, the number of auditors designated firms declined to 24 in 2004 and further steadily down to only 12 in 2008.

Table 1 presents the distribution of the auditor-designated firm-year observations by different reasons (Panel A), and the length of designation (Panel B). Panel A indicates that firms that are manager-owned (256 firm-year observations), firms that have a high debt-to-equity ratio (296 observations), and firms that are under the security trading restriction (221 observations) account for 68 percent of the entire sample of auditor designated observations (although this percentage is only indicative because a firm may be designated for multiple reasons, in which case Panel A of Table 1 counts it multiple times). Panel B presents the distribution of the sample firm-years by the number of consecutive years of designation. Five hundred and twenty three firm-years represent the first year of designation for the respective firm. Since designation has to last at least one year, this implies that the sample size of 1024 firm-years comprises 523 different 
episodes of designation (where consecutive years of designation for a firm constitute a single episode). The average episode therefore lasts just under $2(=1024 / 523)$ years. Of these 523 episodes, 291 (= 523-232, 56 percent $)$ last only one year, i.e., the median episode lasts only a year. Similarly, 99 (=232-133, 19 percent $)$ and 69 episodes $(=133$ 64, 13 percent) last for two and three years, respectively. Hence in 88 percent (= $56+19+13)$ of the cases, firms were released from designation within three years of the initial designation. In one case, the designation episode lasted as long as nine years.

\subsection{Descriptive Statistics}

Table 2 presents the descriptive statistics for the full sample, and for auditordesignated firm-years and non-auditor-designated firm-years separately. The univariate comparison suggests that the audit fees for the auditor-designated firm-years are lower than those for the non-designated firm-years. Audit hours are also lower, although data on audit hours is available only post-2000. Unqualified opinions are fewer in designated firm-years, but given that the comparison is with all other firm-years, it could be because of characteristics of the designated firms, such as their higher leverage, lower ROA, and a greater tendency to report a loss, and not necessarily because of designation itself. Auditor designated firm-years have higher absolute discretionary accruals. Signed discretionary accruals are lower, but the difference is not significant at conventional levels. Auditor designated firm-year observations have smaller total assets. As is not surprising given that the average designation episode lasts under 2 years, ${ }^{12}$ the auditor tenure for designated firm-years is smaller.

\footnotetext{
${ }^{12}$ Moreover, a designated auditor can serve three years at most--the designation episode could last longer, but the FSS rotates the auditor after 3 years. This accounts for the fact that average tenure (1.69 years) is lower than the average length of a designation episode (1.96 years).
} 


\subsection{Auditor Designation Selection Model}

Since the FSS designates client firms having certain characteristics, it is important to control for those characteristics to ensure that any observed relation between designation and audit quality is not due to the omission of variables representing these characteristics. Therefore we include these factors as control variables in our regressions.

To the extent that the FSS selects firms for designation using information unobservable to the researchers, the control variables will not eliminate selection bias (to the extent that the FSS's private information is correlated with the dependent variable of interest, namely audit quality). We correct for this selection bias using the two-stage procedure of Heckman (1979) and Lee (1979). In the first stage, we estimate a probit model with auditor designation dummy as the dependent variable, and the reasons for designation as independent variables. We compute the Inverse Mills Ratio (IMR) for each observation using estimates from the probit model, and include it as an independent variable in the second stage regressions of audit fees or audit quality on their respective determinants. Specifically, we estimate the following probit regression:

$$
\begin{aligned}
& \text { Designatio } \left.\quad n=\beta_{0}+\beta_{1} \log \text { (TotalAsset } s_{-1}\right)+\beta_{2} \text { Liquidity }{ }_{-1}+\beta_{3} \text { Leverage }{ }_{-1}+\beta_{4} \text { Deficit }{ }_{-1} \\
& +\beta_{5} \text { Loss }_{-1}+\beta{ }_{6} \text { Controllin }_{\text {gOwnerHold }} \text { ings }_{-1}+\varepsilon
\end{aligned}
$$

Designation $=1$ if auditor is designated for firm $\mathrm{i}$ in year $\mathrm{t}$, and 0 otherwise,

$\log \left(\right.$ TotalAssets $\left._{-1}\right)=$ logarithm of total assets in year -1 ,

Liquidity $_{-I}=$ current assets divided by current liabilities in year -1 , Leverage $-1_{-1}$ total liabilities divided by total assets in year -1 , Deficit $_{-1}=1$ if owners' equity is less than 0 in year -1 , and 0 otherwise, Loss $_{-1}=1$ if net income is less than 0 in year -1 , and 0 otherwise, ControllingOwnerHoldings $s_{-1}=$ the controlling owner's shareholdings in year -1 , and $\varepsilon=$ the error term. 
The results of the estimation are presented in Table 3. Leverage and ControllingOwnerHoldings are positive and significant as expected, given the numbers of firms designated for those reasons. In addition, Deficit and Loss are also significant. Liquidity is not significant. $\log$ (TotalAssets) is negative and significant, i.e., small client firms are more likely to have their auditors designated.

\subsection{Designated Auditor Fees}

Previous studies (Craswell \& Francis, 1999; Deis \& Giroux, 1996; Ettredge \& Greenberg, 1990; Francis \& Simon, 1987; Sankaraguruswamy \& Whisenant, 2009) find that auditors charge lower fees for initial audit engagements. Given that clients did not voluntarily choose to hire the designated auditor, and that there was no competitive bidding, we do not expect to find lowballing by designated auditors. And given that designated auditors did not have to compete with others to get the job, we expect designated auditor fees to be higher. To check that this is in fact the case, consistent with previous studies (Craswell et al., 1995; Simunic, 1980) we estimate the following audit fee model:

AuditFee $=\alpha_{0}+\alpha_{1}$ Designatio $n+\alpha_{2}$ Designatio $n \times$ InitialDes ignation $\quad+$ $\sum_{k=3}^{N} \alpha_{k}$ Control ${ }_{k}+\varepsilon$

Specifically, the model includes as control variables the following: auditor tenure (Tenure); log of asset size (Log (Total assets)); the ratio of receivables and inventories to total assets (Complexity); ratio of foreign sales to total sales (Export); the debt equity ratio (Leverage); cash from operating activities divided by current liabilities (Liquidity); return on asset $(R O A)$; prior year loss dummy that takes value 1 if a firm experienced loss in the prior year (Loss); Auditor, that takes 1 for Big $\mathrm{N}$ auditors; and Initial, an initial 
audit dummy that takes the value 1 if the audit is an initial audit and 0 otherwise. As explained in Section 3.3, we also include IMR (Lambda) from the designation model as a control variable. In addition, we include fixed-year dummies and industry dummies to control for year and industry effects. Coefficient $a_{1}$ represents the difference in audit fees for auditor designated firm years as compared to all other firm-years, and coefficient $a_{2}$ represents the difference between fees for designated firms in the first year of a designation episode and all other designation years.

Table 4 presents the results of OLS regression of total audit fees on Designation and control variables. In the basic model (1), the coefficient on Designation is 0.252 with a tvalue of 3.66. The sign of most control variables is consistent with the prior expectation. For example, the firms with more subsidiaries, which are likely to pose higher risks for auditors, tend to have higher audit fees. Similarly, audit fees for the Big N auditors are higher, consistent with the findings in the literature. The coefficient of Lambda is negative and significant, suggesting that controlling for the selection bias is important.

The coefficient on Designation $\times$ Initial designation is not significant, suggesting that audit fees of the first year of consecutive designation are not any lower than those of other years in designation. The coefficient on Designation $\times$ Auditor is also insignificant. Overall, the finding in Table 4 provides evidence that designated auditors charge higher audit fees.

\section{$4 \quad$ Research Design and Results}

\subsection{Effect of Designation on Discretionary Current Accruals}

To estimate discretionary accruals, we first calculate current accruals for each sample firm as follows (Sloan, 1996): 
$C A C=$ current accruals,

$C A=$ current assets,

Cash $=$ cash and cash equivalents,

$C L=$ current liabilities, and

$S T D=$ debt included in current liabilities.

We then estimate the parameters of the modified cross-sectional Jones model (Dechow et al., 1995):

$C A C / T A_{-1}=\alpha_{0} / T A_{-1}+\alpha_{1}(\triangle R E V-\triangle R E C) / T A_{-1}+\varepsilon$

$C A C=$ current accruals,

$T A_{-1}=$ total assets in year -1 ,

$R E V=$ revenues,

$R E C=$ receivables, and

$\varepsilon=$ the error term.

The cross-sectional regression model is estimated by industry (two-digit KIS industry code) for each test year separately. We require that an industry have a minimum of 10 member firms (Teoh et al., 1998). We use the residuals estimated from model (4) as the estimates of discretionary (i.e., unexpected) accruals $(D C A C){ }^{13}$

To test whether designated firm-years have higher audit quality, we estimate two crosssectional regression models, with $D C A C$ as the dependent variable, as follows:

\footnotetext{
${ }^{13}$ We replicate all the results with discretionary accruals by using total accruals instead of current accruals. Total accruals are current accruals less depreciation and amortization expense. The cross-sectional modified Jones model for total accruals has total asset scaled property, plant, and equipment as an additional term in equation (4). The unreported results are qualitatively similar to those obtained from current accruals.
} 
DCAC (orAbs _ DCAC $)=\alpha_{0}+\alpha_{1}$ Designatio $n+$

$\alpha_{2}$ Designatio $n \times$ InitialDes ignation $+\sum_{k=3}^{N} \alpha_{k}$ Control ${ }_{k}+\varepsilon$.

In Models 3 and 4 of Table 5, where absolute discretionary current accruals are the dependent variable, the coefficient on Designation is 0.163 and 0.161 , respectively, and significant at the 0.01 level. This indicates that discretionary accruals for the firms with a designated auditor are higher than the control firms. To the extent that higher absolute discretionary accruals proxy for lower-quality audits, this indicates that designated auditors on average provide lower quality audit service. In Model 4, we add an interaction term to the basic model. The coefficients on Designation $\times$ Initial designation and Designation $\times$ Auditor are both insignificant. This suggests that audit quality of the first year of designation is not different from that of other years in consecutive designation. Overall, the results provide evidence that audit quality of the designated auditors is on average lower than that of non-designated auditors. The coefficients on Designation are insignificant in Models 1 and 2.

\subsection{Designation and Audit Hours}

Table 6 provides the relationship between audit hours and auditor designation. The sample is much smaller because audit hours data is available only beginning 2000. In Model 1, the coefficient on Designation is -0.713 which is significant at the 0.05 level. The significantly negative coefficient on Designation indicates that designated auditors put in fewer hours, which in turn suggests that audit quality is lower. In Model 2, we examine whether the initial year of the designation drives the result. The insignificant coefficient on the interaction term of Designation and Initial designation suggests that the finding is not attributable to the initial year of designation. 


\subsection{Other Proxies}

\subsubsection{Benchmark tests}

Following Burgsthaler and Dichev (1997), we test whether net income scaled by market value at the beginning of the period just meets and just misses the zero and prior year benchmarks. ${ }^{14}$ Like them, we group observations based on interval widths of 0.0025 . Table 7 shows the results for (1) just meet zero net income scaled by beginning market value $[0,0.0025]$, (2) just meet prior year net income scaled by beginning market value [0, 0.0025], (3) just miss zero net income scaled by beginning market value [-0.0025, 0], and (4) just miss prior year net income scaled by beginning market value [-0.0025, 0]. In Model 1, the coefficient on Designation is not significant, suggesting that there is no difference in firms' just meeting the benchmark between firms with designated auditors and the rest. In Model 2, however, the coefficient on Designation is -13.571 and significant at the 0.01 level. This is consistent with the interpretation that firms with a designated auditor are less likely to meet the benchmark proxied by prior year net income, indicating that audit quality is higher under designation. Models 3 and 4 present the results for firms' just missing benchmarks. To the extent that audit quality is higher in designated auditors, firms with a designated auditor are more likely to be in the just-miss segment. Hence a positive coefficient on Designation will support the argument that designated auditors provide higher quality audits. The coefficient on Designation in Model 3 is consistent with higher audit quality under designation, but the coefficient is negative and significant in Model 4, which is inconsistent with higher audit quality under

\footnotetext{
${ }^{14}$ Lim and Tan (2008) also use analysts' forecasts, but they are not generally available for the majority of the firms in our sample period.
} 
designation. Overall, the results in table 7 are mixed and do not allow clear interpretation regarding the relationship between audit quality and auditor designation.

One concern, however, is that the number of firm-year in the width of $[0,0.0025]$ or $[-0.0025,0]$ is too small, especially for the zero net income benchmark (i.e., 0.36 percent for Model 1 and 0.15 percent for Model 3). In order to address this concern, we repeat the analysis using several larger intervals. First, we increase the width of the interval fourfold (i.e., $[0,0.01]$ and $[-0.01,0])$ and redo the analysis. This increases the number of firms in the models (1) and (3) to 2.33 percent and 0.71 percent, respectively. Notwithstanding, the qualitative finding is unchanged. Intervals $[0,0.02]$ and $[-0.02,0]$ and $[0,0.03]$ and $[-0.03,0]$ yield the similar results.

Next, we use earnings per share (EPS) instead of scaled earnings. Lim and Tan (2008) use two cents cutoffs to define just meet or miss. Two cents are roughly 25 won in Korean currency. Hence, we use the width [0,30won] and [-30won, 0] for just meet and just miss, respectively. The number of firms that belong to this range is 1.46 percent and 0.5 percent in Models 1 and 3, respectively. The unreported results are qualitatively identical to the results using net income scaled by market value. We repeat the analysis using $[0,20$ won $]$ and $[-20$ won, 0$]$ and again find qualitatively similar results.

\subsubsection{Modified opinion}

We define modified opinion in three different but not mutually exclusive ways: (1) qualified and adverse opinions, (2) going concern modification, (3) both qualified and adverse opinions in (1) and going concern modification combined. (Our data for going concern modification ends in 2003. Hence, for (2) and (3), we use observations in 19932003, losing years 2004-2008.) 
Bradshaw et al. (2001) and Butler et al. (2004) relate accruals to auditors' tendency to issue modified opinion. Lim and Tan (2008) use unqualified opinion with a going concern explanatory paragraph to proxy auditor quality. Bradshaw et al. define modified opinion as (a) qualified opinions, adverse opinions, and unqualified opinions with explanatory language and (b) qualified opinions and adverse opinions. Both Butler et al. and Lim and Tan define modified opinion as unqualified opinion with a going concern explanatory paragraph. ${ }^{15}$ Following the development in the U.S. and International Auditing Standards, the Korean SAS also replaced going concern qualified opinion with unqualified opinion with a going concern explanatory paragraph in 1991. Nevertheless, about 3 percent of the firms in our sample received qualified or adverse opinion, which is more frequent than $0.65 \%$ in the U.S., and supports our choice of the definition of modified opinion.

To the extent that the tendency to issue a modified opinion proxies audit quality and designated auditors are of higher quality, the coefficient on Designation in the logit regression will be positive and significant. Table 8 presents the results using (1) qualified and adverse opinions defined as modified opinion. The coefficient on Designation in both models is insignificant, thus failing to indicate that designated auditors are of higher quality. In unreported analysis using (2) going concern modification or (3) both qualified and adverse opinions in (1) and going concern modification combined, the finding remains qualitatively similar.

\footnotetext{
${ }^{15}$ After Statement on Auditing Standards (SAS) 58 is effective from 1988 in the U.S., only 52 (0.65 percent) firms out of 8,035 observations received either qualified or disclaimer/no opinion--see Table 1 in Butler et al. (2004 p. 145). This is because SAS 58 eliminated going concern qualified opinion and changed it to unqualified opinion with a going concern explanatory paragraph. Clearly, it is not practical to use qualified opinions alone as modified opinions owing to infrequent occurrence. Hence, they define unqualified opinion with a going concern explanatory paragraph as modified opinion. Lim and Tan also employ the same definition of modified opinion.
} 


\subsection{Pre-and Post-Designation Firm-Years as Control}

When we retain only auditor designated firms, dropping the firms that never had their auditor designated during the sample period from the control group, ${ }^{16}$ and repeat the entire analysis we find qualitatively similar results (unreported). Specifically, the coefficient estimate of Designation comparable to that in Model 1 of Table 4 is 0.136 and significant at the 0.1 level, i.e., audit fees are higher during designated firm-years. The coefficient on Designation is -0.023 (0.159) and insignificant (significant) when the dependent variable is signed (absolute) discretionary current accruals, which is also consistent with that reported in Table 5. For audit hours, we find that the coefficient on Designation comparable to that in Model 1 of Table 6 is -1.163 and significant at the 0.01 level. The results from the benchmark and modified opinion tests are also qualitatively unaffected. To the extent that firm characteristics remain constant within a relatively short period, this indicates that our results are unlikely to be attributable to the systematic differences between auditor designated firms and those that never had their auditor designated during the sample period.

Our results on discretionary accruals therefore contradict those of Kim and Yi (2009) who find that audit quality is higher under designation. We have checked that it is attributable to several factors, including the model specification in the auditor designation selection model and the control groups used. ${ }^{17}$ The most notable difference is that the control firm-year observations in Kim and Yi consist solely of the firms that never had their auditor designated during the sample period. This requirement turns out to be taxing,

\footnotetext{
${ }^{16}$ This is the opposite of what Kim and Yi (2009) did, where they took only the firms that never had their auditor designated during the sample period as the control group.

${ }^{17}$ We were able to replicate Kim and Yi's result using the 1993-2000 sample period overlapping with their 1991-2000 sample and their selection model and control group selection method.
} 
eliminating almost one half of firms from entering into the control group. More importantly, the results in this case might be driven by the firm characteristics instead of audit designation per se. That is, if the auditor-designated firms differ systematically from those that have never been designated, then it is possible that results are attributable to these differences. In our study, the control firm-year observations consist of the firmyears of the firms that do not have designated auditors in the particular year. In our study, therefore, the results are more likely to be driven by designation per se.

\subsection{Length of Designation}

To check whether our results are attributable to auditors' incentives to compromise their independence to retain the client post-designation, we repeat our tests on the subsample of observations for designation episodes lasting more than three years (328 firm-years for 64 episodes). If auditors anticipate that designation will last longer than three years they do not have incentives to compromise their independence, because then the law guarantees that they will be rotated out after three years. We find that audit fees are higher, absolute discretionary accruals are higher, and audit hours are lower in this subsample, just as in the full sample. This suggests that our results are unlikely to be attributable to auditors compromising their independence hoping to be re-appointed postdesignation.

\section{Sensitivity Tests}

\subsection{The Results without IMR in the Model}

Considering that auditor designated firms systematically differ from other firms, we believe that controlling for the selection bias is valid. Nevertheless, we redo all the analyses so far without considering the selection bias to check the sensitivity of our 
findings to the selection bias control. In unreported results, none of our results are qualitatively affected, suggesting that our finding is robust to the inclusion or exclusion of IMR.

\subsection{Effect of Release from Designation}

Although not plausible, our results might be attributable to some uncontrolled firm characteristics that change at just the same time as when the FSS decides to designate their auditor. If this characteristic persists after the firm is released from designation, we can test for this possibility by examining audit quality during the first year after a firm is released from auditor designation.

In unreported analysis, we find that audit fees are significantly lower, absolute discretionary accruals are lower, and audit hours are significantly higher in the first year after the firm is released from auditor designation relative to audit fees and audit quality during auditor designation. In fact, both audit fees and audit quality in the first year after the firm is released from auditor designation are indistinguishable from those of the firms that have never been auditor designated. This indicates that our results are unlikely to be attributable to firm characteristics of the auditor-designated firms changing contemporaneously with their designation.

\section{Summary and Conclusions}

The auditor designation rule in Korea, under which the FSS designates the auditor selectively and episodically, provides us a real-world setting to test whether regulator selection of auditors can improve audit quality. Evidence on the issue is important because it has long been believed that client hiring and firing of auditors poses a 
fundamental conflict of interest. In the wake of Enron, several commentators have proposed removing control over hiring and firing of auditors from the client, and giving it instead to a regulator, or the stock exchange, or a shareholder trust supervised by the stock exchange.

Using a variety of measures of audit quality, we are unable to find that audit quality is higher under designation. Our results shed light on the efficacy of the actual reforms in Korea as well as on calls for reforms in the US. However, there is one difference between auditor designation in Korea and the proposed reforms in the US - auditor designation in Korea lasts only 1-2 years in practice while the proposed reforms would permanently remove clients' control over auditor hiring and firing. To the extent that designated auditors in Korea have an incentive to compromise their independence to induce the client to continue them post-designation, our results cannot be generalized to the proposed reforms. However, designation mitigates opinion shopping, reduces competition and the negative effects of the tendering process, and prevents lowballing, as would the proposed reforms. Thus our findings do provide evidence on auditor independence impairment related to these reasons. Also our findings are similar for designation episodes longer than three years where the auditor is compulsorily rotated out, and therefore to the extent that designation is foreseen to be long-lived the auditor has no expectation of continuation. 


\section{References}

Abdel-khalik, A. R. (2002). Reforming corporate governance post Enron: Shareholders' Board of Trustees and the auditor. Journal of Accounting and Public Policy, 21(2), 97-103. doi: 10.1016/S02784254(02)00040-6

Ashbaugh, H., LaFond, R., \& Mayhew, B. W. (2003). Do nonaudit services compromise auditor independence? Further evidence. The Accounting Review, 78(3), 611-639.

Bandyopadhyay, S. P., \& Kao, J. L. (2001). Competition and Big 6 brand name reputation: Evidence from the Ontario municipal audit market. Contemporary Accounting Research, 18(1), 27.

Bartov, E., Gul, F. A., \& Tsui, J. S. L. (2000). Discretionary-accruals models and audit qualifications. Journal of Accounting and Economics, 30(3), 421-452.

Bazerman, M. H., Loewenstein, G., \& Moore, D. A. (2002). Why good accountants do bad audits. Harvard Business Review, 80(11), 96-103.

Bazerman, M. H., Morgan, K. P., \& Loewenstein, G. (1997). The impossibility of auditor independence. Sloan Management Review, 38(4), 89.

Becker, C. L., DeFond, M. L., Jiambalvo, J., \& Subramanyam, K. R. (1998). The effect of audit quality on earnings management. Contemporary Accounting Research, 15(1), 1-24.

Bradshaw, M. T., Richardson, S. A., \& Sloan, R. G. (2001). Do analysts and auditors use information in accruals? Journal of Accounting Research, 39(1), 45-74.

Burgstahler, D., \& Dichev, I. (1997). Earnings management to avoid earnings decreases and losses. Journal of Accounting and Economics, 24(1), 99-126.

Burton, J. C. (1980). A critical look at professionalism and scope of services. The Journal of Accountancy, 149(4), 48-56.

Butler, M., Leone, A. J., \& Willenborg, M. (2004). An empirical analysis of auditor reporting and its association with abnormal accruals. Journal of Accounting and Economics, 37(2), 139-165. doi: 10.1016/j.jacceco.2003.06.004

Carey, P., \& Simnett, R. (2006). Audit Partner Tenure and Audit Quality. The Accounting Review, 81(3), 653-676. doi: 10.2308/accr.2006.81.3.653

Chung, H., \& Kallapur, S. (2003). Client importance, nonaudit services, and abnormal accruals. The Accounting Review, 78(4), 931-955.

Craswell, A. T., \& Francis, J. R. (1999). Pricing Initial Audit Engagements: A Test of Competing Theories. The Accounting Review, 74(2), 201-216.

Craswell, A. T., Francis, J. R., \& Taylor, S. L. (1995). Auditor brand name reputations and industry specializations. Journal of Accounting and Economics, 20(3), 297-322.

Dechow, P. M., Sloan, R. G., \& Sweeney, A. P. (1995). Detecting Earnings Management. The Accounting Review, 70(2), 193-225.

DeFond, M. L., Raghunandan, K., \& Subramanyam, K. R. (2002). Do non-audit service fees impair auditor independence? Evidence from going concern audit opinions. Journal of Accounting Research, 40(4), 1247-1274. 
DeFond, M. L., \& Subramanyam, K. R. (1998). Auditor changes and discretionary accruals. Journal of Accounting and Economics, 25(1), 35-67.

Deis, D. R., \& Giroux, G. (1996). The effect of auditor changes on audit fees, audit hours, and audit quality. Journal of Accounting and Public Policy, 15(1), 55-76. doi: 10.1016/02784254(95)00041-0

Ettredge, M., \& Greenberg, R. (1990). Determinants of Fee Cutting on Initial Audit Engagements. Journal of Accounting Research, 28(1), 198-210.

Fiolleau, K. J., Hoang, K. J., Jamal, K., \& Sunder, S. (2009). Engaging Auditors: Field Investigation of a Courtship. SSRN eLibrary. Retrieved from http://papers.ssrn.com/sol3/papers.cfm?abstract_id=1505497

Francis, J. R., \& Krishnan, J. (1999). Accounting accruals and auditor reporting conservatism. Contemporary Accounting Research, 16(1), 135-165.

Francis, J. R., Michas, P., \& Seavey, S. (2010). Big Four Audit Market Concentration and Client Earnings Quality Around the World. Working paper, University of Missouri-Columbia.

Francis, J. R., \& Simon, D. T. (1987). A Test of Audit Pricing in the Small-Client Segment of the U. S. Audit Market. Accounting Review, 62(1), 145-157.

Frankel, R. M., Johnson, M. F., \& Nelson, K. K. (2002). The relation between auditors' fees for nonaudit services and earnings management. The Accounting Review, 77(Supplement), 71-105.

Ghosh, A., \& Moon, D. (2005). Auditor Tenure and Perceptions of Audit Quality. The Accounting Review, $80(2), 585-612$.

Hackenbrack, K., Jensen, K. L., \& Payne, J. L. (2000). The Effect of a Bidding Restriction on the Audit Services Market. Journal of Accounting Research, 38(2), 355-374.

Heckman, J. J. (1979). Sample Selection Bias as a Specification Error. Econometrica, 47(1), 153-161.

Hilzenrath, D. (2001, December 5). After Enron, New Doubts About Auditors (washingtonpost.com). The Washington Post. Retrieved from http://www.washingtonpost.com/ac2/wpdyn?pagename=article \&node $=\&$ contentId=A58165-2001Dec 4

J Hamilton, Ruddock, C., Stokes, D., \& Taylor, S. (2005). Audit partner rotation, earnings quality and earnings conservatism. Working Paper, University of Technology, Sydney, Australia.

Johnson, V. E., Khurana, I. K., \& Reynolds, J. K. (2002). Audit-firm tenure and the quality of financial reports. Contemporary Accounting Research, 19(4), 637-660.

Kallapur, S., Sankaraguruswamy, S., \& Zang, Y. (2011). Audit Market Concentration and Audit Quality. Working paper, Indian School of Business, National University of Singapore, and Singapore Management University.

Kim, J.-B., \& Yi, C. H. (2009). Does auditor designation by the regulatory authority improve audit quality? Evidence from Korea. Journal of Accounting and Public Policy, 28(3), 207-230. doi: 10.1016/j.jaccpubpol.2009.04.006

King, R. R. (2002). An Experimental Investigation of Self-Serving Biases in an Auditing Trust Game: The Effect of Group Affiliation. The Accounting Review, 77(2), 265-284. 
Kinney Jr, W. R. (2000). Testimony of William R. Kinney, Jr. on S7-13-00. Retrieved November 3, 2011, from http://www.sec.gov/rules/proposed/s71300/testimony/kinney1.htm

Koo, C. M., \& Sim, H. S. (1999). On the role conflict of auditors in Korea. Accounting, Auditing \& Accountability Journal, 12(2), 206-219. doi: 10.1108/09513579910270110

Lee, H. I. (1990). The impacts of auditor change on audit opinion based on independence under free engagement system. Korean Accounting Review, 11, 181-216.

Lee, L.-F. (1979). Identification and Estimation in Binary Choice Models with Limited (Censored) Dependent Variables. Econometrica, 47(4), 977-996.

Lim, C.-Y., \& Tan, H.-T. (2008). Non-audit Service Fees and Audit Quality: The Impact of Auditor Specialization. Journal of Accounting Research, 46(1), 199-246.

Maher, M. W., Tiessen, P., Colson, R., \& Broman, A. J. (1992). Competition and Audit Fees. Accounting Review, 67(1), 199-211.

Mayhew, B. W., \& Pike, J. E. (2004). Does Investor Selection of Auditors Enhance Auditor Independence? The Accounting Review, 79(3), 797-822. doi: 10.2308/accr.2004.79.3.797

Myers, J. N., Myers, L. A., \& Omer, T. C. (2003). Exploring the term of the auditor-client relationship and the quality of earnings: A case for mandatory auditor rotation. The Accounting Review, 78(3), 779-799.

Newton, N. J., Wang, D., \& Wilkins, M. S. (2011). Does a Lack of Choice Lead to Lower Quality? Evidence from Auditor Competition and Client Restatements. Working Paper, Texas A\&M University.

O'Connor, S. M. (2004). Be Careful What You Wish For: How Accountants and Congress Created the Problem of Auditor Independence. Boston College Law Review, 45, 741-826.

O'Connor, S. M. (2006). Strengthening Auditor Independence: Reestablishing Audits as Control and Premium Signaling Mechanisms. Washington Law Review, 81, 525-593.

Palepu, K., \& Healy, P. M. (2003). How the quest for efficiency undermined the market. Harvard Business Review, 81(7), 76-85.

Palmrose, Z.-V. (1989). The Relation of Audit Contract Type to Audit Fees and Hours. Accounting Review, 64(3), 488-499.

Ronen, J. (2010). Corporate audits and how to fix them. The Journal of Economic Perspectives, 24(2), 189-210.

Sankaraguruswamy, S., \& Whisenant, S. (2009). Pricing Initial Audit Engagements: Empirical Evidence Following Public Disclosure of Audit Fees. SSRN eLibrary. Retrieved from http://papers.ssrn.com/sol3/papers.cfm?abstract_id=452680

Saul, R. S. (1996). What ails the accounting profession? Accounting Horizons, 10(2), 131.

Shapiro, A. (2005). Who Pays the Auditor Calls the Tune?: Auditing Regulation and Clients' Incentives. Seton Hall Law Review, 35(3), 1029-1095.

Simunic, D. A. (1980). The Pricing of Audit Services: Theory and Evidence. Journal of Accounting Research, 18(1), 161-190. 
Sloan, R. G. (1996). Do Stock Prices Fully Reflect Information in Accruals and Cash Flows about Future Earnings? The Accounting Review, 71(3), 289-315.

Teoh, S. H., Welch, I., \& Wong, T. J. (1998). Earnings management and the underperformance of seasoned equity offerings. Journal of Financial Economics, 50(1), 63-99. 
Figure 1

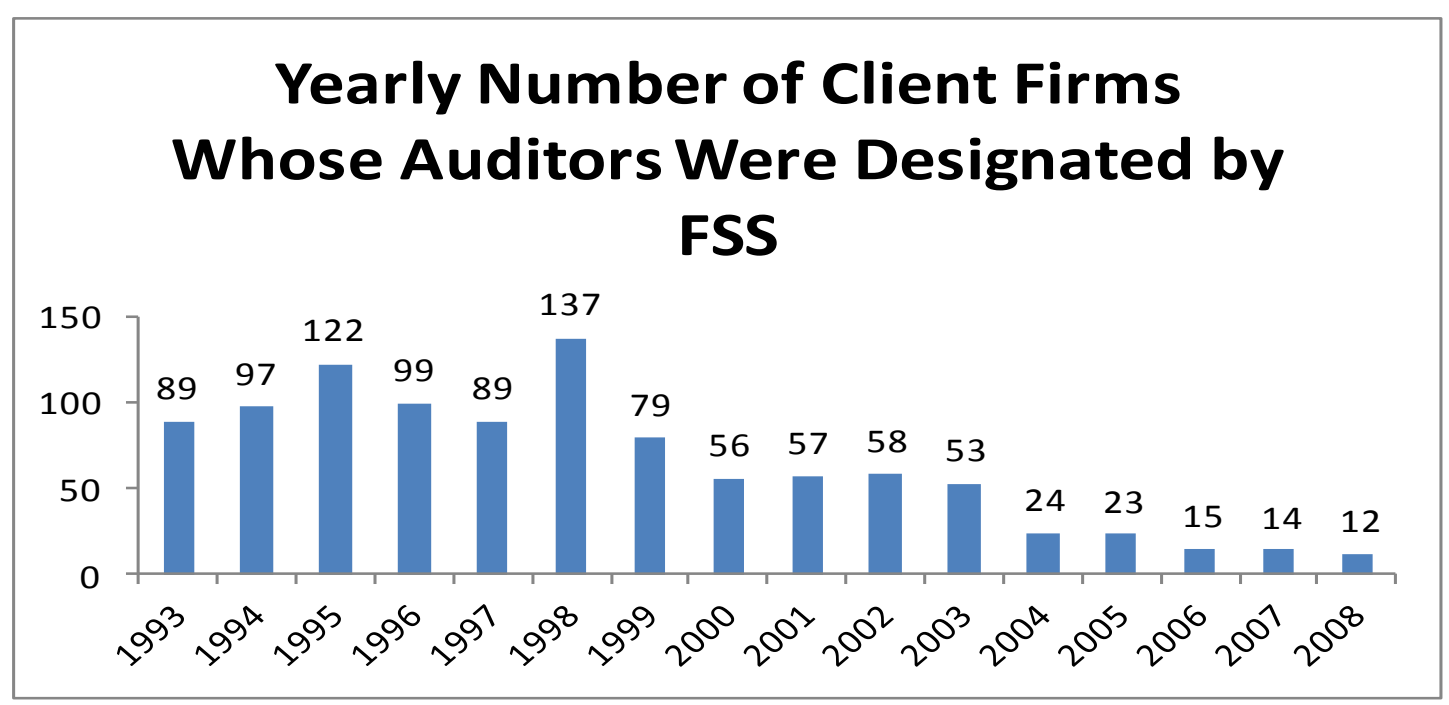


Table 1

Sample selection procedure and distribution of sample firms

Panel A: Number of firm-year observations by the reasons for auditor designation

\begin{tabular}{ll}
\hline Reason for designation & Number of firm years \\
\hline Problems in the prior year's audit detected by & 62 \\
$\quad$ peer review & \\
Manager-owned & 256 \\
Under the security trading restriction & 221 \\
Did not hire an auditor & 6 \\
Changed auditors for improper reasons & 10 \\
Large related firm lending & 59 \\
Firms in industries undergoing restructuring & 36 \\
Large debt ratio & 296 \\
Violation of security laws & 8 \\
Voluntary designation & 5 \\
Violation of the fair trade laws & 5 \\
Unidentified & 161 \\
\hline Total & 1125 \\
\hline
\end{tabular}

Some firms have multiple reasons for designation, which explains why the total exceeds the number of firm years in our sample.

Panel B: Distribution of sample firm-years by cumulative years of consecutive designation

\begin{tabular}{cc}
\hline Year of consecutive designation & Number of observations \\
\hline 1 & 523 \\
2 & 232 \\
3 & 133 \\
4 & 64 \\
5 & 42 \\
6 & 22 \\
7 & 5 \\
8 & 2 \\
9 & 1 \\
\hline Total & 1024
\end{tabular}

There are 523 first-designated-year observations, i.e., there are 523 episodes of designation. Of these, 232 continue for the second year, i.e., 291 (=523-232) episodes end after just one year of designation. 
Table 2

Descriptive statistics: mean and (median) for the sample and control firms

\begin{tabular}{|c|c|c|c|c|}
\hline & $\begin{array}{l}\text { All firm year } \\
\text { observations }\end{array}$ & $\begin{array}{c}\text { Auditor } \\
\text { designated firm- } \\
\text { year observations }\end{array}$ & $\begin{array}{c}\text { Control firm- } \\
\text { year observations }\end{array}$ & $\begin{array}{c}\text { Test of } \\
\text { difference: } \mathrm{t}[\mathrm{z}]- \\
\text { value }\end{array}$ \\
\hline Log (Auditfees) & $\begin{array}{c}10.866 \\
(10.775)\end{array}$ & $\begin{array}{c}10.637 \\
(10.470)\end{array}$ & $\begin{array}{c}10.895 \\
(10.820)\end{array}$ & $\begin{array}{c}11.45 * * * \\
{[12.36]^{* * *}}\end{array}$ \\
\hline Log(Audit hours) & $\begin{array}{c}5.745 \\
(6.397)\end{array}$ & $\begin{array}{c}4.874 \\
(5.375)\end{array}$ & $\begin{array}{c}5.795 \\
(6.405)\end{array}$ & $\begin{array}{c}6.45^{* * *} \\
{[5.45]^{* * *}}\end{array}$ \\
\hline Modified opinion & $\begin{array}{l}0.031 \\
(0)\end{array}$ & $\begin{array}{l}0.088 \\
(0)\end{array}$ & $\begin{array}{l}0.024 \\
(0)\end{array}$ & $\begin{array}{c}7.14 * * * \\
{[11.22]^{* * *}}\end{array}$ \\
\hline$D C A C$ & $\begin{array}{c}0.003 \\
(0.002)\end{array}$ & $\begin{array}{l}-0.003 \\
(0.002)\end{array}$ & $\begin{array}{c}0.004 \\
(0.003)\end{array}$ & $\begin{array}{c}1.44 \\
{[0.63]}\end{array}$ \\
\hline$A b s \_D C A C$ & $\begin{array}{c}0.088 \\
(0.057)\end{array}$ & $\begin{array}{c}0.098 \\
(0.066)\end{array}$ & $\begin{array}{c}0.087 \\
(0.056)\end{array}$ & $\begin{array}{c}2.92 * * * \\
{[3.40] * * *}\end{array}$ \\
\hline Complexity & $\begin{array}{c}0.294 \\
(0.282)\end{array}$ & $\begin{array}{c}0.295 \\
(0.279)\end{array}$ & $\begin{array}{c}0.294 \\
(0.283)\end{array}$ & $\begin{array}{c}0.21 \\
{[0.00]}\end{array}$ \\
\hline Liquidity & $\begin{array}{c}1.671 \\
(1.257)\end{array}$ & $\begin{array}{c}1.414 \\
(1.082)\end{array}$ & $\begin{array}{c}1.703 \\
(1.282)\end{array}$ & $\begin{array}{c}5.44 * * * \\
{[9.02] * * *}\end{array}$ \\
\hline Export & $\begin{array}{c}0.284 \\
(0.157)\end{array}$ & $\begin{array}{c}0.244 \\
(11.149)\end{array}$ & $\begin{array}{c}0.289 \\
(0.162)\end{array}$ & $\begin{array}{c}4.63^{* * * *} \\
{[4.64]^{* * *}}\end{array}$ \\
\hline Loss & $\begin{array}{l}0.225 \\
(0)\end{array}$ & $\begin{array}{c}0.356 \\
(0)\end{array}$ & $\begin{array}{l}0.208 \\
(0)\end{array}$ & $\begin{array}{c}4.22 * * * \\
{[10.74]^{* * *}}\end{array}$ \\
\hline$R O A$ & $\begin{array}{c}0.015 \\
(0.024)\end{array}$ & $\begin{array}{l}-0.013 \\
(0.010)\end{array}$ & $\begin{array}{c}0.019 \\
(0.026)\end{array}$ & $\begin{array}{c}6.62 * * * \\
{[9.41] * * *}\end{array}$ \\
\hline Leverage & $\begin{array}{c}0.595 \\
(0.572)\end{array}$ & $\begin{array}{c}0.851 \\
(0.765)\end{array}$ & $\begin{array}{c}0.562 \\
(0.554)\end{array}$ & $\begin{array}{c}8.49 * * * \\
{[23.88]^{* * *}}\end{array}$ \\
\hline Log(Total assets) & $\begin{array}{c}26.065 \\
(25.854)\end{array}$ & $\begin{array}{c}25.778 \\
(25.563)\end{array}$ & $\begin{array}{c}26.101 \\
(25.889)\end{array}$ & $\begin{array}{c}6.98 * * * \\
{[6.36]^{* * *}}\end{array}$ \\
\hline $\begin{array}{l}\text { Log(Market } \\
\text { value })\end{array}$ & $\begin{array}{c}24.904 \\
(24.630)\end{array}$ & $\begin{array}{c}24.183 \\
(24.015)\end{array}$ & $\begin{array}{c}24.981 \\
(24.704)\end{array}$ & $\begin{array}{c}13.84 * * * \\
{[13.03] * * *}\end{array}$ \\
\hline$M B$ & $\begin{array}{c}1.255 \\
(0.704)\end{array}$ & $\begin{array}{c}1.257 \\
(0.749)\end{array}$ & $\begin{array}{c}1.056 \\
(0.701)\end{array}$ & $\begin{array}{c}1.18 \\
{[0.68]}\end{array}$ \\
\hline$N I / M V$ & $\begin{array}{l}-0.115 \\
(0.070)\end{array}$ & $\begin{array}{l}-0.520 \\
(0.036)\end{array}$ & $\begin{array}{l}-0.072 \\
(0.073)\end{array}$ & $\begin{array}{c}3.41 * * * \\
{[7.51]}\end{array}$ \\
\hline$\Delta N I / M V$ & $\begin{array}{c}0.044 \\
(0.004)\end{array}$ & $\begin{array}{c}0.370 \\
(0.014)\end{array}$ & $\begin{array}{c}0.009 \\
(0.004)\end{array}$ & $\begin{array}{l}2.15^{* *} \\
{[3.80]}\end{array}$ \\
\hline Tenure & $\begin{array}{c}4.783 \\
(3.0)\end{array}$ & $\begin{array}{c}1.692 \\
(1)\end{array}$ & $\begin{array}{l}5.177 \\
(4.0)\end{array}$ & $\begin{array}{c}59.11 * * * \\
{[31.59] * * *}\end{array}$ \\
\hline$O C F$ & $\begin{array}{c}0.043 \\
(0.047)\end{array}$ & $\begin{array}{c}0.032 \\
(0.033)\end{array}$ & $\begin{array}{c}0.044 \\
(0.045)\end{array}$ & $\begin{array}{c}1.62 * \\
{[4.62]^{* * *}}\end{array}$ \\
\hline Deficit & $\begin{array}{c}0.030 \\
(0)\end{array}$ & $\begin{array}{l}0.116 \\
(0)\end{array}$ & $\begin{array}{l}0.019 \\
(0)\end{array}$ & $\begin{array}{c}9.64 * * * \\
{[17.36] * * *}\end{array}$ \\
\hline $\begin{array}{l}\text { Controlling } \\
\text { OwnerHoldings } \\
(\%)\end{array}$ & $\begin{array}{c}31.137 \\
(29.505)\end{array}$ & $\begin{array}{c}31.236 \\
(30.350)\end{array}$ & $\begin{array}{c}31.125 \\
(29.400)\end{array}$ & $\begin{array}{c}0.17 \\
{[0.55]}\end{array}$ \\
\hline Auditor & $\begin{array}{l}0.559 \\
(1.0)\end{array}$ & $\begin{array}{l}0.502 \\
(1.0)\end{array}$ & $\begin{array}{l}0.566 \\
(1.0)\end{array}$ & $\begin{array}{c}3.85^{* * *} \\
{[3.87]^{* * *}}\end{array}$ \\
\hline
\end{tabular}




\begin{abstract}
Number of observations 5131 to $9050 \quad 303$ to 1024 4850 to 8026

$\log ($ Audit fees $)=\operatorname{logarithm}$ of audit fees; Modified opinion $=1$ if audit opinion is other than unqualified, 0 otherwise; $D C A C=$ discretionary current accruals from the modified Jones model; $A b s \_D C A C=$ absolute value of discretionary current accruals; Complexity $=$ receivables plus inventories $\div$ total assets; Liquidity $=$ current assets $\div$ current liabilities; Export $=$ foreign sales $\div$ total sales; Loss $=1$ if the firm has a loss in year $-1,0$ otherwise; $R O A=$ net income in year -1 $\div$ total assets in year -2 ; Leverage $=$ total liabilities $\div$ total assets $; \log ($ Totalassets $)=\operatorname{logarithm}$ of total assets; $\log ($ Market value $)=$ logarithm of market value; $M B=$ market value $\div$ book value; $N I / M V=$ net income $\div$ market value; $\triangle N I / M V=$ change in net income $\div$ market value; Tenure $=$ number of years audited by the incumbent auditor; $O C F=$ cash flows from operations $\div$ total assets in year -1 ; Deficit $=1$ if owners equity is smaller than 0,0 otherwise; ContorllingOwnerHoldings =the controlling owner's shareholdings; Auditor $=1$ for a Big N auditor, 0 otherwise.
\end{abstract}


Table 3

Probit regression: auditor designation selection model

\begin{tabular}{|c|c|c|c|c|}
\hline \multirow[b]{2}{*}{ Variable } & \multicolumn{4}{|c|}{ Dependent variable $=$ Auditor designation dummy } \\
\hline & Coefficient & $\begin{array}{l}\text { Standard } \\
\text { error }\end{array}$ & $\begin{array}{l}\text { Wald chi- } \\
\text { square }\end{array}$ & p-value \\
\hline Intercept & -0.596 & 0.352 & 2.863 & 0.091 \\
\hline $\log \left(\right.$ Total assets $\left._{-1}\right)$ & -0.039 & 0.013 & 8.604 & 0.003 \\
\hline Liquidity $_{-1}$ & -0.023 & 0.014 & 2.458 & 0.117 \\
\hline Leverage $_{-1}$ & 0.171 & 0.068 & 6.360 & 0.012 \\
\hline Deficit $_{-1}$ & 0.660 & 0.108 & 37.245 & 0.000 \\
\hline Loss. $_{-1}$ dummy & 0.483 & 0.043 & 127.271 & 0.000 \\
\hline \multirow[t]{2}{*}{ ControllingOwnerHoldings $s_{-1}$} & 0.353 & 0.101 & 12.130 & 0.001 \\
\hline & Chi-square & p-value & & \\
\hline Likelihood ratio test & 428.938 & 0.000 & & \\
\hline Score test & 600.850 & 0.000 & & \\
\hline Wald test & 374.351 & 0.000 & & \\
\hline $\begin{array}{l}\text { Percent concordant or tie } \\
\text { (discordant) }\end{array}$ & $72.5(27.5)$ & & & \\
\hline Pseudo R-Squared & 0.094 & & & \\
\hline
\end{tabular}

Designatio $\quad n=\beta_{0}+\beta_{1} \log$ (Totalasset $\left.\quad s-1\right)+\beta_{2}$ Liquidity $\quad-1+\beta_{3}$ Leverage $-1+\beta_{4}$ Deficit -1

$+\beta_{5}$ Loss $-1+\beta_{6}$ Controllin gOwnerHold ings $-1+\varepsilon$

Designation $=1$ if auditor is designated for firm, and 0 otherwise,

$\log \left(\right.$ TotalAssets $\left._{-1}\right)=\operatorname{logarithm}$ of total assets in year-1,

Liquidity $_{-1}=$ current assets divided by current liabilities in year-1,

Leverage $_{-1}=$ total liabilities divided by total assets in year-1,

Deficit $_{-1}=1$ if owners' equity is less than 0 in year-1, and 0 otherwise,

Loss $_{-1}=1$ if net income is less than 0 in year -1 , and 0 otherwise,

ContorllingOwnerHolding $S_{-1}=$ the controlling owner's shareholdings in year -1 , and

$\varepsilon=$ the error term. 
Table 4

Parameter estimates for OLS regressions of Log (Audit fees) on Designation and control variables

\begin{tabular}{|c|c|c|}
\hline & \multicolumn{2}{|c|}{ Dependent variable $=\log ($ Audit fees } \\
\hline Independent variable & $(1)$ & $(2)$ \\
\hline Intercept & $\begin{array}{c}0.936^{* * *} \\
(9.63)\end{array}$ & $\begin{array}{c}0.955^{* * *} \\
(9.76)\end{array}$ \\
\hline Designation & $\begin{array}{c}0.252^{* * * *} \\
(3.66)\end{array}$ & $\begin{array}{c}0.241 * * * \\
(3.42)\end{array}$ \\
\hline Designation $\times$ Initial designation & & $\begin{array}{r}-0.020 \\
(0.74)\end{array}$ \\
\hline Designation $\times$ Auditor & & $\begin{array}{l}0.013 \\
(0.49)\end{array}$ \\
\hline $\log ($ Total assets $)$ & $\begin{array}{c}0.380 * * * \\
(111.42)\end{array}$ & $\begin{array}{c}0.379 * * * \\
(111.25)\end{array}$ \\
\hline Tenure & $\begin{array}{c}0.004 * * * \\
(3.74)\end{array}$ & $\begin{array}{c}0.005^{* * *} \\
(4.39)\end{array}$ \\
\hline Complexity & $\begin{array}{c}0.071 * * \\
(2.25)\end{array}$ & $\begin{array}{c}0.071^{* *} \\
(2.25)\end{array}$ \\
\hline Export & $\begin{array}{c}0.001 * * * \\
(3.26)\end{array}$ & $\begin{array}{c}0.001 * * * \\
(3.26)\end{array}$ \\
\hline Leverage & $\begin{array}{c}-0.038 * * \\
(2.37)\end{array}$ & $\begin{array}{c}-0.037 * * \\
(2.33)\end{array}$ \\
\hline Liquidity & $\begin{array}{c}-0.019 * * * \\
(5.96)\end{array}$ & $\begin{array}{c}-0.019 * * * \\
(6.02)\end{array}$ \\
\hline$R O A$ & $\begin{array}{c}-0.126 * * * \\
(4.23)\end{array}$ & $\begin{array}{c}-0.126^{* * * *} \\
(4.23)\end{array}$ \\
\hline Loss & $\begin{array}{c}0.050 * * * \\
(4.15)\end{array}$ & $\begin{array}{c}0.050 * * * \\
(4.17)\end{array}$ \\
\hline ControllingOwnerHoldings & $\begin{array}{l}-0.040 \\
(1.62)\end{array}$ & $\begin{array}{l}-0.038 \\
(1.56)\end{array}$ \\
\hline Auditor & $\begin{array}{c}0.082^{* * * *} \\
(9.25)\end{array}$ & $\begin{array}{c}0.080 * * * \\
(8.59)\end{array}$ \\
\hline Initial & & $\begin{array}{c}0.029 * * \\
(2.38)\end{array}$ \\
\hline Lambda & $\begin{array}{c}-0.105 * * * \\
(2.91)\end{array}$ & $\begin{array}{c}-0.101 * * * \\
(2.79)\end{array}$ \\
\hline Fixed-year dummies & Included & Included \\
\hline Industry dummies & Included & Included \\
\hline F-value & 735.30 & 674.42 \\
\hline Adjusted R-Squared & 0.743 & 0.743 \\
\hline $\begin{array}{l}\text { Number of } \\
\text { observations }\end{array}$ & 8399 & 8399 \\
\hline
\end{tabular}


$\log ($ Audit fees $)=\operatorname{logarithm}$ of audit fees; Designation $=1$ if auditor is designated for firm $\mathrm{i}$ in year $\mathrm{t}$, and 0 otherwise; Initial designation $=1$ if $\mathrm{t}$ is the first year in a designation episode, and 0 otherwise; Auditor $=1$ for a Big N auditor, 0 otherwise; $\log$ (Total assets) $=$ logarithm of total assets; Tenure $=$ number of years audited by the incumbent auditor; Complexity $=$ receivables plus inventories $\div$ total assets; Export $=$ foreign sales $\div$ total sales; Leverage $=$ total liabilities $\div$ total assets; Liquidity $=$ current assets $\div$ current liabilities; $R O A=$ net income $\div$ total assets in year -1 ; Loss $=1$ if the firm has a loss, 0 otherwise; ControllingOwnerHoldings $=$ the controlling owner's shareholdings; Initial $=1$ if initial audit, and 0 otherwise; Lambda $=$ the inverse Mills ratio from the probit model for designation. The $\mathrm{t}$-values are in parentheses. ${ }^{*},{ }^{* *}$, and ${ }^{* * *}$ denotes significance at the $0.1,0.05$, and 0.01 level, respectively. 
Table 5

Parameter estimates for OLS regressions of Signed and absolute Discretionary Current Accruals on Designation variables and control variables

\begin{tabular}{|c|c|c|c|c|}
\hline \multirow[b]{2}{*}{ Independent variable } & \multicolumn{2}{|c|}{$\begin{array}{l}\text { Dependent variable }=\text { Signed } \\
\text { discretionary current accruals } \\
(D C A C)\end{array}$} & \multicolumn{2}{|c|}{$\begin{array}{c}\text { Dependent variable }=\text { Absolute } \\
\text { discretionary current accruals } \\
\left(A b s \_D C A C\right)\end{array}$} \\
\hline & (1) & (2) & (3) & (4) \\
\hline Intercept & $\begin{array}{c}-0.431 * * * \\
(13.26)\end{array}$ & $\begin{array}{c}-0.430 * * * \\
(13.24)\end{array}$ & $\begin{array}{l}0.498 * * * \\
(21.38)\end{array}$ & $\begin{array}{c}0.498 * * * \\
(21.33)\end{array}$ \\
\hline Designation & $\begin{array}{l}-0.023 \\
(1.05)\end{array}$ & $\begin{array}{l}-0.019 \\
(0.85)\end{array}$ & $\begin{array}{c}0.163 * * * \\
(10.38)\end{array}$ & $\begin{array}{l}0.161 * * * \\
(9.90)\end{array}$ \\
\hline $\begin{array}{l}\text { Designation } \times \text { Initial } \\
\text { designation }\end{array}$ & & $\begin{array}{l}0.010 \\
(0.99)\end{array}$ & & $\begin{array}{l}0.001 \\
(0.21)\end{array}$ \\
\hline Designation $\times$ Auditor & & $\begin{array}{l}-0.015 \\
(1.54)\end{array}$ & & $\begin{array}{c}0.0003 \\
(0.05)\end{array}$ \\
\hline $\log ($ Total assets $)$ & $\begin{array}{c}0.004 * * * \\
(3.07)\end{array}$ & $\begin{array}{c}0.003 * * * \\
(3.04)\end{array}$ & $\begin{array}{c}-0.006 * * * \\
(7.39)\end{array}$ & $\begin{array}{c}-0.006^{* * * *} \\
(7.42)\end{array}$ \\
\hline Tenure & $\begin{array}{l}-0.000 \\
(0.55)\end{array}$ & $\begin{array}{l}-0.000 \\
(0.69)\end{array}$ & $\begin{array}{c}-0.001 * * * \\
(2.85)\end{array}$ & $\begin{array}{l}-0.001 * * \\
(2.01)\end{array}$ \\
\hline Leverage & $\begin{array}{c}-0.023 * * * \\
(6.91)\end{array}$ & $\begin{array}{l}-0.023 * * * \\
(6.94)\end{array}$ & $\begin{array}{l}-0.003 \\
(1.11)\end{array}$ & $\begin{array}{l}-0.003 \\
(1.09)\end{array}$ \\
\hline Accruals $_{-1}$ & $\begin{array}{c}-0.052 * * * \\
(6.99)\end{array}$ & $\begin{array}{c}-0.052 * * * \\
(7.01)\end{array}$ & $\begin{array}{l}0.006 \\
(1.10)\end{array}$ & $\begin{array}{l}0.006 \\
(1.10)\end{array}$ \\
\hline$R O A_{-1}$ & $\begin{array}{l}-0.000 \\
(0.08)\end{array}$ & $\begin{array}{l}0.000 * * * \\
(0.04)\end{array}$ & $\begin{array}{l}0.002 \\
(0.76)\end{array}$ & $\begin{array}{l}0.002 \\
(0.78)\end{array}$ \\
\hline$O C F$ & $\begin{array}{l}-0.011 \\
(1.39)\end{array}$ & $\begin{array}{l}-0.011 \\
(1.44)\end{array}$ & $\begin{array}{c}-0.042 * * * \\
\quad(7.33)\end{array}$ & $\begin{array}{c}-0.042 * * * \\
\quad(7.31)\end{array}$ \\
\hline ControllingOwnerHoldings & $\begin{array}{l}0.012 \\
(1.43)\end{array}$ & $\begin{array}{l}0.012 \\
(1.40)\end{array}$ & $\begin{array}{l}-0.010 \\
(1.58)\end{array}$ & $\begin{array}{l}-0.009 \\
(1.52)\end{array}$ \\
\hline Auditor & $\begin{array}{l}-0.003 \\
(1.05)\end{array}$ & $\begin{array}{l}-0.002 \\
(0.49)\end{array}$ & $\begin{array}{l}0.002 \\
(1.00)\end{array}$ & $\begin{array}{l}0.002 \\
(0.92)\end{array}$ \\
\hline Initial & & $\begin{array}{l}-0.002 \\
(0.25)\end{array}$ & & $\begin{array}{l}0.004 \\
(1.32)\end{array}$ \\
\hline Lambda & $\begin{array}{l}0.008 \\
(0.73)\end{array}$ & $\begin{array}{l}0.009 \\
(0.73)\end{array}$ & $\begin{array}{c}-0.085 * * * \\
(10.29)\end{array}$ & $\begin{array}{c}-0.085 * * * \\
(10.25)\end{array}$ \\
\hline Fixed-year dummies & Included & Included & Included & Included \\
\hline Industry dummies & Included & Included & Included & Included \\
\hline F-value & 52.77 & 48.21 & 66.29 & 60.50 \\
\hline Adjusted R-Squared & 0.166 & 0.166 & 0.200 & 0.200 \\
\hline $\begin{array}{l}\text { Number of } \\
\text { observations }\end{array}$ & 8094 & 8094 & 8094 & 8094 \\
\hline
\end{tabular}


$D C A C=$ discretionary current accruals from the modified Jones model; $A b s \_D C A C=$ absolute value of discretionary current accruals; Designation $=1$ if auditor is designated for firm $\mathrm{i}$ in year $\mathrm{t}$, and 0 otherwise; Initial designation $=1$ if the first year in a designation episode, and 0 otherwise; Auditor $=1$ for a Big N auditor, 0 otherwise; $\log$ (Total assets) = logarithm of total assets; Tenure $=$ number of years audited by the incumbent auditor; Leverage $=$ total liabilities : total assets; Accruals $_{-1}=$ total accruals in year $-1 ; R O A_{-1}=$ net income in year $-1 \div$ total assets in year $-2 ; O C F=$ cash flows from operations $\div$ total assets in year -1 ; ControllingOwnerHoldings $=$ the controlling owner's shareholdings; Initial $=1$ if initial audit, and 0 otherwise; Lambda = the inverse Mills ratio from the probit model for designation. The $\mathrm{t}$-values are in parentheses. ${ }^{*},{ }^{* *}$, and $^{* * *}$ denotes significance at the $0.1,0.05$, and 0.01 level, respectively. 
Table 6

Parameter estimates for OLS regressions of Log (Audit hours) on Designation and control variables

\begin{tabular}{|c|c|c|}
\hline & \multicolumn{2}{|c|}{ Dependent variable $=\log ($ Audit hours $)$} \\
\hline Independent variable & (1) & $(2)$ \\
\hline Intercept & $\begin{array}{c}-3.589 * * * \\
(8.18)\end{array}$ & $\begin{array}{c}-3.579 * * * \\
(8.16)\end{array}$ \\
\hline Designation & $\begin{array}{c}-0.713^{* *} \\
(2.29)\end{array}$ & $\begin{array}{c}-0.916^{* * * *} \\
(2.79)\end{array}$ \\
\hline Designation $\times$ Initial designation & & $\begin{array}{l}0.235 \\
(1.44)\end{array}$ \\
\hline Designation $\times$ Auditor & & $\begin{array}{l}0.165 \\
(1.03)\end{array}$ \\
\hline $\log ($ Total assets) & $\begin{array}{c}0.391 * * * \\
(25.86)\end{array}$ & $\begin{array}{c}0.391 * * * \\
(25.82)\end{array}$ \\
\hline Tenure & $\begin{array}{c}0.014 * * * \\
(3.42)\end{array}$ & $\begin{array}{c}0.016^{* * *} \\
(3.46)\end{array}$ \\
\hline Complexity & $\begin{array}{l}-0.022 \\
(0.16)\end{array}$ & $\begin{array}{l}-0.026 \\
(0.19)\end{array}$ \\
\hline Export & $\begin{array}{l}0.001 \\
(1.19)\end{array}$ & $\begin{array}{l}0.001 \\
(1.13)\end{array}$ \\
\hline Leverage & $\begin{array}{l}0.002 \\
(0.02)\end{array}$ & $\begin{array}{l}-0.000 \\
(0.00)\end{array}$ \\
\hline Liquidity & $\begin{array}{l}-0.013 \\
(1.11)\end{array}$ & $\begin{array}{l}-0.013 \\
(1.14)\end{array}$ \\
\hline$R O A$ & $\begin{array}{l}0.006 \\
(0.06)\end{array}$ & $\begin{array}{l}0.004 \\
(0.04)\end{array}$ \\
\hline Loss & $\begin{array}{l}-0.082 \\
(1.57)\end{array}$ & $\begin{array}{l}-0.081 \\
(1.55)\end{array}$ \\
\hline ControllingOwnerHoldings & $\begin{array}{c}-0.312 * * * \\
(3.18)\end{array}$ & $\begin{array}{c}-0.311^{* * *} \\
(3.16)\end{array}$ \\
\hline Auditor & $\begin{array}{c}0.334 * * * \\
(8.60)\end{array}$ & $\begin{array}{c}0.307 * \\
(1.86)\end{array}$ \\
\hline Initial & & $\begin{array}{l}0.036 \\
(0.70)\end{array}$ \\
\hline Lambda & $\begin{array}{l}0.297 * \\
(1.80)\end{array}$ & $\begin{array}{l}0.307 * \\
(1.86)\end{array}$ \\
\hline Fixed-year dummies & Included & Included \\
\hline Industry dummies & Included & Included \\
\hline F-value & 287.33 & 258.80 \\
\hline Adjusted R-squared & 0.612 & 0.613 \\
\hline $\begin{array}{l}\text { Number of } \\
\text { observations }\end{array}$ & 4895 & 4895 \\
\hline
\end{tabular}


$\log ($ Audit hours $)=$ logarithm of audit hours; Designation $=1$ if auditor is designated for firm $\mathrm{i}$ in year $\mathrm{t}$, and 0 otherwise; Initial designation $=1$ if the first year in a designation episode, and 0 otherwise; Auditor $=1$ for a Big N auditor, 0 otherwise; $\log$ (Total assets) $=$ logarithm of total assets; Tenure $=$ number of years audited by the incumbent auditor; Complexity $=$ receivables plus inventories $\div$ total assets; Export $=$ foreign sales $\div$ total sales; Leverage $=$ total liabilities $\div$ total assets; Liquidity $=$ current assets $\div$ current liabilities; $R O A=$ net income $\div$ total assets in year -1 ; Loss $=1$ if the firm has a loss, 0 otherwise; ControllingOwnerHoldings $=$ the controlling owner's shareholdings; Initial $=1$ if initial audit, and 0 otherwise; Lambda $=$ the inverse Mills ratio from the probit model for designation. The $t$-values are in parentheses. ${ }^{*},{ }^{* *}$, and ${ }^{* * *}$ denotes significance at the $0.1,0.05$, and 0.01 level, respectively. 
Table 7

Parameter estimates for logistic regressions of meet/miss on designation and control variables

\begin{tabular}{|c|c|c|c|c|}
\hline \multirow[b]{2}{*}{ Independent variable } & \multicolumn{2}{|c|}{$\begin{array}{l}\text { Dependent variable = } \\
\text { Just meet dummy }\end{array}$} & \multicolumn{2}{|c|}{$\begin{array}{l}\text { Dependent variable }= \\
\text { Just miss dummy }\end{array}$} \\
\hline & $\begin{array}{l}\text { Target }=\text { Net } \\
\text { income } 0\end{array}$ & $\begin{array}{l}\text { Target = prior year } \\
\text { net income }\end{array}$ & $\begin{array}{l}\text { Target }=\text { Net } \\
\text { income } 0\end{array}$ & $\begin{array}{l}\text { Target }=\text { prior } \\
\text { year net income }\end{array}$ \\
\hline & $\begin{aligned} 0 & <\mathrm{NI} / \mathrm{MV} \\
& <0.0025\end{aligned}$ & $\begin{aligned} 0 & <\Delta \mathrm{NI} / \mathrm{MV} \\
& <0.0025\end{aligned}$ & $\begin{array}{l}-0.0025< \\
\text { NI/MV }<0\end{array}$ & $\begin{array}{l}-0.0025< \\
\Delta \mathrm{NI} / \mathrm{MV}<0\end{array}$ \\
\hline & (1) & (2) & (3) & (4) \\
\hline Intercept & $\begin{array}{l}-4.632 \\
(1.76)\end{array}$ & $\begin{array}{l}-8.375^{* * *} \\
(27.36)\end{array}$ & $\begin{array}{l}-9.657 * \\
(2.77)\end{array}$ & $\begin{array}{l}-9.589 * * * \\
(21.82)\end{array}$ \\
\hline Designation & $\begin{array}{l}-6.436 \\
(0.21)\end{array}$ & $\begin{array}{l}-13.571 * * * \\
(11.91)\end{array}$ & $\begin{array}{l}5.571 \\
(1.67)\end{array}$ & $\begin{array}{l}-13.88 * * * \\
(11.12)\end{array}$ \\
\hline Tenure & $\begin{array}{l}-0.118 \\
(2.45)\end{array}$ & $\begin{array}{l}-0.004 \\
(0.03)\end{array}$ & $\begin{array}{l}0.044 \\
(0.23)\end{array}$ & $\begin{array}{l}-0.014 \\
(0.39)\end{array}$ \\
\hline Leverage & $\begin{array}{l}0.159 \\
(0.020)\end{array}$ & $\begin{array}{l}-1.370 * * * \\
(6.81)\end{array}$ & $\begin{array}{l}-4.918 * * \\
(5.32)\end{array}$ & $\begin{array}{l}-0.665 \\
(1.33)\end{array}$ \\
\hline$D C A C$ & $\begin{array}{l}-0.679 \\
(0.11)\end{array}$ & $\begin{array}{l}-1.43 \\
(2.58)\end{array}$ & $\begin{array}{l}-4.003 \\
(1.14)\end{array}$ & $\begin{array}{l}0.122 \\
(0.16)\end{array}$ \\
\hline$R O A$ & $\begin{array}{l}0.107 \\
(0.01)\end{array}$ & $\begin{array}{l}1.232 \\
(1.80)\end{array}$ & $\begin{array}{l}2.220 \\
(0.26)\end{array}$ & $\begin{array}{l}1.484 * * * \\
(6.69)\end{array}$ \\
\hline$O C F$ & $\begin{array}{l}-0.418 \\
(0.257)\end{array}$ & $\begin{array}{l}-1.042 * \\
(2.73)\end{array}$ & $\begin{array}{l}-1.105 \\
(0.18)\end{array}$ & $\begin{array}{l}-1.337 * * * \\
(8.18)\end{array}$ \\
\hline Log(Market value) & $\begin{array}{l}0.025 \\
(0.04)\end{array}$ & $\begin{array}{l}0.243 * * * \\
(20.90)\end{array}$ & $\begin{array}{l}0.203 \\
(1.03)\end{array}$ & $\begin{array}{l}0.209 * * * \\
(11.73)\end{array}$ \\
\hline$M B$ & $\begin{array}{l}0.040 \\
(1.55)\end{array}$ & $\begin{array}{l}0.004 \\
(2.11)\end{array}$ & $\begin{array}{l}0.087 * * * \\
(8.69)\end{array}$ & $\begin{array}{l}0.003 \\
(0.16)\end{array}$ \\
\hline Auditor & $\begin{array}{l}0.839^{*} \\
(2.90)\end{array}$ & $\begin{array}{l}0.053 \\
(0.08)\end{array}$ & $\begin{array}{l}-0.374 \\
(0.27)\end{array}$ & $\begin{array}{l}0.183 \\
(0.78)\end{array}$ \\
\hline Lambda & $\begin{array}{l}1.918 \\
(0.37)\end{array}$ & $\begin{array}{l}6.681 * * * \\
(11.93)\end{array}$ & $\begin{array}{l}-2.602 \\
(1.21)\end{array}$ & $\begin{array}{l}7.121 * * * \\
(12.09)\end{array}$ \\
\hline Fixed-year dummies & Included & Included & Included & Included \\
\hline Industry dummies & Included & Included & Included & Included \\
\hline Likelihood ratio test & 45.89 & 140.76 & 55.10 & 78.48 \\
\hline Score test & 43.08 & 123.31 & 56.96 & 58.47 \\
\hline Wald test & 25.12 & 115.51 & 31.13 & 60.55 \\
\hline Concordant or tie & $86.2 \%$ & $76.2 \%$ & $95.5 \%$ & $74.7 \%$ \\
\hline Pusedo R-Squared & 0.131 & 0.101 & 0.336 & 0.070 \\
\hline $\begin{array}{l}\text { Frequency of just } \\
\text { meet or miss }\end{array}$ & $\begin{array}{l}27 / 7345 \\
{[0.36 \%]}\end{array}$ & $\begin{array}{c}158 / 7345 \\
{[2.15 \%]}\end{array}$ & $\begin{array}{l}11 / 7345 \\
{[0.15 \%]}\end{array}$ & $\begin{array}{l}119 / 7345 \\
{[1.62 \%]}\end{array}$ \\
\hline
\end{tabular}

$N I / M V=$ net income $\div$ market value; $\triangle N I / M V=$ change in net income $\div$ market value;

Designation $=1$ if auditor is designated for firm $\mathrm{i}$ in year $\mathrm{t}$, and 0 otherwise; Tenure $=$ number of years audited by the incumbent auditor; Leverage $=$ total liabilities $\div$ total assets; $D C A C=$ discretionary current accruals from the modified Jones model; $R O A=$ net income $\div$ 
total assets in year $-1 ; O C F=$ cash flows from operations $\div$ total assets in year $-1 ;$ Log (Market value $)=\operatorname{logarithm}$ of market value; $M B=$ market value $\div$ book value; Auditor $=1$ for a Big $\mathrm{N}$ auditor, 0 otherwise; Lambda $=$ the inverse Mills ratio from the probit model for designation. Wald Chi-Square in parenthesis. ${ }^{*},{ }^{* *}$, and ${ }^{* * *}$ denotes significance at the $0.1,0.05$, and 0.01 level, respectively. 
Table 8

Parameter estimates for logistic regressions of modified opinion on designation and control variables

\begin{tabular}{|c|c|c|}
\hline \multirow[b]{2}{*}{ Independent variable } & \multicolumn{2}{|c|}{ Dependent variable $=$ Modified opinion dummy } \\
\hline & (1) & (2) \\
\hline \multirow[t]{2}{*}{ Intercept } & -1.552 & -2.456 \\
\hline & $(1.05)$ & $(2.30)$ \\
\hline \multirow[t]{2}{*}{ Designation } & 1.204 & -0.748 \\
\hline & $(0.52)$ & $(0.18)$ \\
\hline \multirow[t]{2}{*}{ Designation $\times$ Initial designation } & & -0.292 \\
\hline & & $(0.83)$ \\
\hline \multirow[t]{2}{*}{ Designation $\times$ Auditor } & & $0.777 * *$ \\
\hline & & $(5.37)$ \\
\hline \multirow[t]{2}{*}{ Log (Total assets) } & $-0.154 * * *$ & $-0.123 * *$ \\
\hline & $(8.11)$ & $(4.70)$ \\
\hline \multirow[t]{2}{*}{ Tenure } & $-0.038 *$ & -0.025 \\
\hline & $(2.95)$ & $(0.93)$ \\
\hline \multirow[t]{2}{*}{ Leverage } & $0.925 * * *$ & $0.845^{* * *}$ \\
\hline & $(25.62)$ & $(18.58)$ \\
\hline \multirow[t]{2}{*}{ Liquidity } & -0.006 & 0.030 \\
\hline & $(0.01)$ & $(0.27)$ \\
\hline \multirow[t]{2}{*}{$R O A$} & 0.120 & $-0.624 * *$ \\
\hline & $(0.41)$ & $(3.98)$ \\
\hline \multirow[t]{2}{*}{ Loss } & $2.231 * * *$ & $2.014 * * *$ \\
\hline & $(131.92)$ & $(97.14)$ \\
\hline \multirow[t]{2}{*}{ Loss $_{-1}$} & $0.572 * *$ & $0.775 * * *$ \\
\hline & $(4.96)$ & $(8.00)$ \\
\hline \multirow[t]{2}{*}{ Deficit-1 } & 0.137 & 0.402 \\
\hline & $(0.07)$ & $(0.55)$ \\
\hline \multirow[t]{2}{*}{ ControllingOwnerHoldings } & $-1.716^{* * *}$ & $-1.408 * * *$ \\
\hline & $(14.35)$ & $(8.76)$ \\
\hline \multirow[t]{2}{*}{ Auditor } & 0.188 & -0.011 \\
\hline & (1.64) & $(0.00)$ \\
\hline \multirow[t]{2}{*}{ Initial } & & 0.133 \\
\hline & & $(0.43)$ \\
\hline \multirow[t]{2}{*}{ Lambda } & 0.531 & 0.399 \\
\hline & $(0.33)$ & $(0.16)$ \\
\hline Fixed-year dummies & Included & Included \\
\hline Industry dummies & Included & Included \\
\hline Likelihood ratio test & 775.925 & 712.626 \\
\hline Score test & 1233.435 & 1208.979 \\
\hline Wald test & 487.984 & 472.971 \\
\hline Percent concordant or tie & $92.0 \%$ & $92.0 \%$ \\
\hline
\end{tabular}




$\begin{array}{lcc}\text { Pseudo R-Squared } & 0.362 & 0.354 \\ \text { Frequency of modified opinion } & 261 / 8616[3.0 \%] & 261 / 8616[3.0 \%]\end{array}$

Modified opinion $=$ if audit opinion is other than unqualified, 0 otherwise; Designation $=1$ if auditor is designated for firm $\mathrm{i}$ in year $\mathrm{t}$, and 0 otherwise; Initial designation $=1$ if the first year in a string of the consecutive designation, and 0 otherwise; Auditor $=1$ for a Big $\mathrm{N}$ auditor, 0 otherwise; $\log ($ Total assets $)=$ logarithm of total assets; Tenure $=$ number of years audited by the incumbent auditor; Leverage $=$ total liabilities $\div$ total assets; Liquidity $=$ current assets $\div$ current liabilities; $R O A=$ net income $\div$ total assets in year -1 ; Loss $=1$ if the firm has a loss, and 0 otherwise; Loss $1=1$ if the firm has a loss in year -1 , and 0 otherwise; Deficit $1=1$ if the firm has negative owners' equity in year -1 , and 0 otherwise; ControllingOwnerHoldings $=$ the controlling owner's shareholdings; Initial $=1$ if initial audit, and 0 otherwise; Lambda $=$ the inverse Mills ratio from the probit model. Wald Chi-Square in parenthesis. ${ }^{*}, * *$, and ${ }^{* * *}$ denotes significance at the $0.1,0.05$, and 0.01 level, respectively. 